Published by Al-Nahrain College of Medicine P-ISSN 1681-6579

E-ISSN 2224-4719

Email: iraqijms@colmed-alnahrain.edu.iq

http://www.colmed-alnahrain.edu.iq

http://www.iraqijms.net

Iraqi JMS 2018; Vol. 16(4)

\title{
Deficiency of Serum 25-hydroxyvitamin D in Patients with Breast Cancer in Iraq
}

\author{
Taha H.T. Al-Saigh FICMS
}

Dep.t of Surgery, Nineveh college of Medicine, University of Nineveh, Iraq

\section{Abstract \\ Background}

Objective

Methods

Results

Conclusion

\section{Keywords \\ Citation}

Many studies defined the association between vitamin $D$ and breast cancer. The relation between human epidermal growth factor receptor 2 (Her2/nue), estrogen or progesterone receptors and vitamin $D$ in breast cancer patients was not clear, since few studies was conducted.

To find out the association of deficiency of vitamin D and breast cancer. The effect of Her2/neu, estrogen, and progesterone receptors on vitamin $\mathrm{D}$ in the breast cancer patients was also studied.

Forty patients with benign breast lump as a control group and 40 patients with breast cancer early diagnosed were included in the study. Blood samples $(5 \mathrm{~mL})$ were taken from the control and patient groups and analyzed for serum 25-hydroxyvitamin D by using chemiluminescent immunoassay technology. Serum cancer antigen (CA15-3) was measured by using monoclonal antibodies against CA15-3. HER2/neu, estrogen and progesterone receptors were determined in breast cancer patients by immunochemical method.

Serum vitamin $D$ in the breast cancer patients before surgery was significantly lower $(p \leq 0.05)$ than that in the control group. Preoperatively, serum CA15-3 in Her2/neu positive patients was significantly ( $p \leq 0.05$ ) higher than that in Her2/neu negative patients. Postoperatively, serum CA15-3 in Her2/neu positive patients was not significantly different from that in Her2/neu negative patients. Serum vitamin D, after surgery, in Her2/neu positive patients was not significantly different from that in Her2/neu negative patients. Serum vitamin D was not significantly different in estrogen and progesterone positive patients from that in estrogen and progesterone negative patients, respectively.

Severe deficiency of vitamin D was noticed in breast cancer patients in Iraq, and mild deficiency in benign subjects. Serum CA15-3 was higher in positive Her2/neu than negative patients before operation. Her2/neu, estrogen and progesterone positive receptors have no effect on serum vitamin $D$ level in breast cancer patients.

Vitamin D, breast cancer, CA15-3, Her2/neu

Al-Saigh THT. Deficiency of serum 25-hydroxyvitamin D in patients with breast cancer in Iraq. Iraqi JMS. 2018; 16(4): 400-404. doi: 10.22578/IJMS.16.4.7
List of abbreviations: None

\section{Introduction}

he association of vitamin D with calcium

$\Omega$

hemostasis is elucidated for decades, vitamin $D$ also plays a role on other disease states such as metabolic syndrome, type 2 diabetes, and systemic hypertension (1). Serum vitamin D deficiency was significantly associated to colorectal, breast and prostate cancer risk (2). Relation of breast cancer risk and vitamin D status has been defined in many studies but the true association is still not understood and needs further research ${ }^{(3,4)}$. Preclinical and some 
clinical studies strongly suggest that vitamin D deficiency increased risk of developing cancer and that avoiding deficiency and adding vitamin D supplements outcome reduced risk of breast cancer (5). Accordingly, it is recommended to maintain vitamin $D$ store in breast cancer survivors ${ }^{(6)}$. However, high 25 hydroxyvitamin D was weakly associated with low risk of breast cancer ${ }^{(7)}$. Further studies are needed to clarify the potential role of vitamin $D$ and breast cancer risk ${ }^{(8)}$.

High hypovitaminosis $D$ was found in many countries including USA, China, and Iran ${ }^{(9-11)}$. In Europe vitamin $D$ deficiency was less prominent than other countries ${ }^{(12)}$. The indoor life and the dressing style play an important role for vitamin D deficiency in Iraq, even with the sunny weather during most of the year. Therefore, measurement of serum vitamin $D$ should be considered and made regularly.

Few studies were managed to find out the relation of vitamin $D$ and human epidermal growth factor receptor 2 (Her2/neu) (13). Vitamin D supplementation improved the life of breast cancer patients with Her2/neu positive ${ }^{(14)}$.

This work was conducted in order to evaluate the association of vitamin $D$ and breast cancer. The effect of Her2/neu, estrogen and progesterone positive receptors on serum vitamin $D$ level in the breast cancer patients was also studied.

\section{Methods}

This study was conducted at Nineveh Medical Center and Al-Jammhory Teaching Hospital, Mosul, Iraq during the period from February
2013 to Jun 2013. Eighty patients were divided into two groups according to their presentation into: 40 patients with benign breast lump with mean age $34.45 \pm$ SD: 10.45 years and 40 patients with breast cancer early diagnosed with mean age $44.85 \pm$ SD: 10.73 years. Blood samples $(5 \mathrm{~mL})$ were taken from the patients before surgery and from the control subjects and analyzed for serum 25-hydroxyvitamin D by chemiluminescent immunoassay technology (Liaison instrument, DiaSorin Company, Germany). Kit by serum cancer antigen (CA153) was also measured in the breast cancer patients by immunochemical method by using monoclonal antibodies against CA15-3 (Minividas, USA, Kids by Biomerieux Company, France). HER2/neu, estrogen and progesterone receptors were determined in breast cancer patients by immunochemical method (Dako Company, Denmark).

Data are presented as mean \pm SD and were analyzed by using non-paired t-test. $p$ values $\leq$ 0.05 were considered significant. Statistical analysis was performed by using SPSS version 16.

\section{Results}

The breast cancer patients suffered from severe deficiency in serum vitamin $D$, while the control (benign breast lump) suffered from mild deficiency. This classification of severe and moderate is according to the American College of Cardiology (1). Serum vitamin D before surgery in the breast cancer patients was significantly ( $p \leq 0.05$ ) lower than that in the benign breast lump subject (Table 1 ).

Table 1. Serum vitamin $D$ in patients with breast cancer and in subjects with benign breast lump

\begin{tabular}{cccc}
\hline Variables & $\begin{array}{c}\text { Benign breast lump } \\
\text { subjects }(\mathrm{n}=\mathbf{4 0})\end{array}$ & $\begin{array}{c}\text { Breast cancer patients } \\
(\mathrm{n}=\mathbf{4 0 )}\end{array}$ & p-value \\
\hline Vitamin D ng/mL & $18.39 \pm 4.11$ & $7.31 \pm 2.93$ & $\leq 0.05$ \\
\hline
\end{tabular}


Preoperatively, serum CA15-3 in Her2/neu positive patients was significantly ( $p \leq 0.05$ ) higher than that in Her2/neu negative patients. Postoperatively, serum CA15-3 in Her2/neu positive patients was not significantly different from that in Her2/neu negative patients. Serum vitamin $D$ in Her2/neu positive patients was not significantly different from that in Her2/neu negative patients (Table 2).

Serum vitamin $D$ was not significantly different in estrogen and progesterone positive patients from that in estrogen and progesterone negative patients, respectively (Data not shown).

Table 2. Serum cancer antigen 15-3 pre-operative and post-operative, vitamin $D$ in patients with positive human epidermal receptor and negative human epidermal receptor in breast cancer

\begin{tabular}{cccc}
\hline Variables & HER2/neu positive & HER2/neu negative & p-value \\
\hline CA 15-3 pre-operative & $48.42 \pm 16.74$ & $\mathbf{N}=\mathbf{1 6}$ & 41.88 \pm 10.3 \\
CA 15-3 post-operative & $27.33 \pm 11.43$ & $23.19 \pm 7.74$ & N S \\
Vitamin D ng/mL & $7.64 \pm 3.42$ & $6.82 \pm 2.01$ & N S \\
\hline
\end{tabular}

\section{Discussion}

In the present study, serum vitamin $D$ in the breast cancer patients before surgery was significantly lower than that in the control subjects. The results are consistent with other workers ${ }^{(15)}$. Vitamin D deficiency is correlated with poor outcome of patients with breast cancer ${ }^{(7)}$. In addition, high vitamin D levels correlated with low tumor size and high better survivals ${ }^{(16)}$.

In the present study, breast cancer patients suffered from severe deficiency in serum vitamin $D$, while the control group (benign breast) suffered from mild deficiency.

Alipour et al. found that severe vitamin D deficiency produces three folds' increase in the risk of breast cancer patients, the median serum vitamin $D$ level was higher in the control subjects, lower in benign mass and the lowest in breast cancer patients (17).

In this study, CA15-3 in Her2/neu positive patients was higher than that in the negative patients. Hashim (18) also noticed high CA15-3 in Her2/neu positive patients. Serum Her2/neu and CA15-3 were useful marker for aggressiveness of breast cancer (19). Serum CA15-3 level was significantly higher in the breast cancer patients compared with the control group, and this level dropped after surgery ${ }^{(19)}$.

No significant difference between Her2/neu positive and negative for the present serum vitamin D. The 25-hydroxyvitamin D concentration was inversely associated with prognosis of patients with cancer estrogen positive but not with Her2/neu positive (20). Furthermore, in disease free survival of breast cancer women, vitamin D deficiency had negative correlation related to Her2/neu receptor expression (21).

No significant difference between estrogen or progesterone positive or negative receptors for serum vitamin D was noticed in this work. Cell culture strongly support and in vivo data in mice that vitamin $D$ would play a beneficial role in prevention of estrogen positive breast cancer (22). Calcitriol suppresses estrogen expression and estrogen mediated signaling (23). Vitamin D down regulate estrogen receptor and thereby attenuates estrogen signaling in breast cancer (24). However, deficiency of vitamin $D$ levels were shown to be a risk factor estrogen negative tumor (25).

In conclusion, severe deficiency of vitamin D was noticed in breast cancer patients in Iraq, and mild deficiency in benign subjects. Serum CA15-3 was higher in positive Her2/neu than 
negative patients before operation. No relationship was measured between positive receptors of Her2/neu, estrogen or progesterone, and serum vitamin $D$ in breast cancer patients.

\section{Acknowledgments}

To laboratory team in Al-Jammhoy Hostital.

\section{Conflict of interest}

None.

\section{Funding}

This work was supported by Nineveh College of Medicine, University of Mosul.

\section{References}

1. Lavie CJ, Lee JH, Milani RV. Vitamin D and cardiovascular disease. J Am Coll Cardiol. 2011; 58(15): 1547-56. doi: 10.1016/j.jacc.2011.07.008.

2. Ordóñez Mena JM, Brenner H. Vitamin D and cancer: an overview on epidemiological studies. Adv Exp Med Biol. 2014; 810: 17-32.

3. Lopes N, Sousa B, Martins D, et al. Alteration in vitamin $D$ signaling and metabolic pathways in breast cancer progression: A study of VDR, CYP27B1 and CYP24A1 expression in benign and malignant breast lesions. BMC Cancer. 2010; 10: 483 . doi: 10.1186/1471-2407-10-483.

4. Shao $T$, Klein $P$, Grossbard ML. Vitamin $D$ and Breast Cancer. Oncologist 2012; 17(1): 36-45. doi: 10.1634/theoncologist.2011-0278.

5. Feldman D, Krishnan AV, Swami S, et al. The role of vitamin $D$ in reducing cancer risk and progression. Nat Rev Cancer. 2014; 14(5): 345-57. doi: 10.1038/nrc3691.

6. Hines SL, Jorn HK, Thompson KM, et al. Breast cancer survivors and vitamin D: A review. Nutrition. 2009; 26(3): 255-62. doi: 10.1016/j.nut.2009.08.020.

7. Kim HJ, Lee YM, Ko BS, et al. Vitamin D deficiency is correlated with poor outcomes in patients with luminal-type breast cancer. Ann Surg Oncol. 2011; 18(7): 1830-6. doi: 10.1245/s10434-010-1465-6.

8. Yin L, Grandi N, Raum E, et al. Meta-analysis: serum vitamin D and breast risk. Eur J Cancer. 2010; 46(12): 2196-205. doi: 10.1016/j.ejca.2010.03.037.

9. Forrest KY, Stuhldreher WL. Prevalence and correlates of vitamin D deficiency in USA adults. Nutr Res. 2011; 31(1): 48-54. doi: 10.1016/j.nutres.2010.12.001.

10. Shi L, Nechuta S, Gao YT, et al. Correlates of 25hydroxyvitamin $\mathrm{D}$ among Chinese breast cancer patients. PLoS One. 2014; 9(1): e86467. doi: $10.1371 /$ journal.pone.0086467.
11. Jamshidinaeini $Y$, Akbari $M E$, Abdollahi $M$, et al. Vitamin $D$ status and risk of breast cancer in Iranian women: a case-control study. J Am Coll Nutr. 2016; 35(7): 639-46. doi: 10.1080/07315724.2015.1127786.

12. Spiro A. Buttriss JL. Vitamin D: an overview of vitamin D status and intake in Europe. Nutr Bull. 2014; 39(4): 322-50. doi: 10.1111/nbu.12108.

13.Zhang $X$, Harbeck $N$, Jeschke $U$, et al. Influence of vitamin $D$ signaling on hormone receptor status and HER2 expression in breast cancer. J Cancer Res Clin Oncol. 2017; 143(7): 1107-22. doi: 10.1007/s00432-016-2325-y.

14. Zeichner SB, Koru-Sengul T, Shah N, et al. Improved clinical outcomes associated with vitamin D supplementation during adjuvant chemotherapy in patients with HER2+ nonmetastatic breast cancer. Clin Breast Cancer. 2015; 15(1): e1-11. doi: 10.1016/j.clbc.2014.08.001.

15. Yousef FM, Jacobs ET, Kang PT, et al. Vitamin D status and breast cancer in Saudi Arabian women: case control study. Am J Clin Nutr. 2013; 98(1): 105-10. doi: 10.3945/ajcn.112.054445.

16. Hatse S, Lambrechts D, Verstuyf A, et al. Vitamin $D$ status at breast cancer diagnosis: correlation with tumor characteristics, disease outcome, and genetic determinants of vitamin D insufficiency. Carcinogenesis. 2012; 33(7): 1319-26. doi: 10.1093/carcin/bgs187.

17. Alipour S, Hadji M, Hosseini L, et al. Levels of serum 25-hydroxy-vitamin $d$ in benign and malignant breast masses. Asian Pac J Cancer Prev. 2014; 15(1): 129-32. doi: http://dx.doi.org/10.7314/APJCP.2014.15.1.129.

18. Hashim ZM. The significant of CA15-3 in breast cancer patients and its relationship to HER-2 receptor status. Int J Immunopathol Pharmacol. 2014: 27(1): 45-51. doi: 10.1177/039463201402700107.

19. Samy N, Ragab HM, Al Maksoud NA, et al. Prognostic significance of serum Her2/neu, BCL2, CA15-3, CEA in breast cancer patients: a short follow up. Cancer Biomark. 2010; 6(1): 63-72. doi: 10.3233/CBM-20090119.

20. Kim Y, Je, Y. Vitamin D intake, blood 25(OH)D levels, and breast cancer risk or mortality: A metaanalysis. Br. J. Cancer. 2014; 110(11): 2772-84. doi: 10.1038/bjc.2014.175.

21. Ismail A, El-Awady R, Mohamed G, et al. Prognostic significance of serum vitamin $D$ levels in Egyptian females with breast cancer. Asian Pac J Cancer Prev. 2018; 19(2): 571-6. doi: 10.22034/APJCP.2018.19.2.571.

22. Krishnan AV, Swami S, Feldman D. The potential therapeutic benefits of vitamin $D$ in the treatment of estrogen receptor positive breast cancer. Steroid. 2012; 77(11): 1107-12. doi: 10.1016/j.steroids.2012.06.005. 
23. Swami S, Krishnan AV, Peng L, et al. Transrepression of the estrogen receptor promoter by calcitriol in human breast cancer cells via two negative vitamin $D$ response elements. Endocr Relat Cancer. 2013; 20(4): 565-77. doi: 10.1530/ERC-12-0281.

24. Krishnan AV, Swami S, Feldman D. Vitamin $D$ and breast cancer: inhibition of estrogen synthesis and signaling. J Steroid Biochem Mol Biol. 2010; 121(1-2): 343-8. doi: 10.1016/j.jsbmb.2010.02.009.

25. de Sousa Almeida-Filho B, De Luca Vespoli H, Pessoa $E C$, et al. Vitamin D deficiency is associated with poor breast cancer prognostic features in postmenopausal women. J Steroid Biochem Mol Biol. 2017 174: 284-9. doi:

\section{E-mail: t.alsaigh@yahoo.com \\ Received Jan. $23^{\text {rd }} 2018$ \\ Accepted Jun.14 ${ }^{\text {th }} 2018$}

